\author{
Efeito da incorporação de agregados com alto \\ teor de sulfetos nas propriedades mecânicas \\ e microestruturais de concretos com \\ cimento de escória
}

\title{
Effect of the incorporation of aggregates with high sulfide content on the mechanical and microstructural properties of concrete with slag cement
}

\author{
Maria de Jesus Gomides ${ }^{1}$, Denise Coitinho Carpena Dal Molin ${ }^{2}$, \\ João Henrique da Silva Rêgo ${ }^{3}$
}

\footnotetext{
${ }^{1}$ Federal Institute of Education, Science and Technology of Goiás, Câmpus Aparecida de Goiânia. NUPECOCI leader. Av. Universitária Vereador Vagner da Silva Ferreira, Qd-1, Lt 1-A - Parque Itatiaia. 74968-755. Aparecida de Goiânia/GO - Brazil.

email: ziza.gomides@gmail.com; maria.gomides@ifg.edu.br

${ }^{2}$ Federal University of Rio Grande do Sul, School of Engineering, Department of Civil Engineering. Av. Osvaldo Aranha, 99, 3 andar. Cidade Baixa. 90035-190. Porto Alegre/ RS - Brazil. email: dmolin@ufrgs.br

${ }^{3}$ University of Brasília, Environmental and Civil Engineering Department. Campus Universitário Darcy Ribeiro, Asa Norte, 70910-900, Brasília/DF - Brazil.

email: jhenriquerego@unb.br
}

\begin{abstract}
The mineralogical change in the sulfides present in many aggregates can affect their stability, which may undermine the performance of the concrete. This is a complex process and there is limited research in this area. In this study, we examined the influence of aggregates containing a high sulfide content on the performance of concrete containing slag cement. The sulfides present in the aggregates were initially identified and quantified. The changes at the microstructural level of the concrete caused by the sulfide-containing aggregates were then examined. These included volume changes, as well as their effect on the compressive strength and modulus of elasticity. The results show that slag cement does not reduce expansion, and it is this expansion that affects the mechanical properties of concrete.
\end{abstract}

Keywords: sulfide; oxidation; expansion; strength; concrete.

\section{INTRODUCTION}

Economic and environmental factors are very important when choosing the construction materials, especially for large constructions, as for instance hydraulic structures. In most cases, to build these structures a large volume of rock material from different extraction processes is discarded into the environment. The ideal situation therefore is to use this debris as a constituent material of concrete or as part of the construction. To carry this out, however, it is crucial to assure its quality, as well as the durability of the concrete. Therefore, the rocks should be studied in-depth and the alteration process of the sulfides in the aggregates from these rocks must be investigated prior to their use in the concrete.

Concrete deterioration associated with the use of sulfide-containing aggregates may occur as a result of the expansion phenomenon which can develop due to two very different mechanisms. The first mechanism may occur because of the alteration process of sulfide itself, which besides iron hydroxide $\left[\mathrm{Fe}(\mathrm{OH})_{3}\right]$ such as goethite, can arise from other expanding compounds such as melanterite, pickeringite, laumonite, jarosite, fibroferrite and gypsum $[1,2,3]$. When formed, these products can initially promote the expansion of the aggregate, as well as the consequent cracking and fragmentation of this material over time [3, 4]. Some studies $[3,4,5,6]$ have shown that the presence of cracks extending through the cement paste from the fragment- 
ed aggregate can be considered a typical and evident feature of the aggregate's expansion, a phenomenon that can undermine the durability of concrete.

The second mechanism is related to the concrete subjected to internal sulfate attack. According to a number of different studies [1, 2, 7], aggregates containing sulfide minerals can become an internal source of sulfate ions. It is known that the presence of sulfate ions in the pore solution of concrete can promote the development of chemical reactions between these aggressive ions, released by the aforementioned sulfide alteration, and the cement paste composition, which may result in the formation of expansive and deleterious products that are typical of sulfate attack known as ettringite, gypsum and thaumasite [7, 8, 9].

Regarding the main symptoms that characterize a concrete structure attacked by internal sulfidecontaining aggregates are mapping and/or oriented cracks on the concrete surface; rust stains on the concrete surface; superficial white efflorescence; expansion due to the formation of hydrated iron sulfates and iron hydroxides; $\mathrm{pH}$ reduction of concrete due to the consumption of calcium hydroxide in the system; expansion due to the formation of ettringite and swelling and disaggregation of the concrete due to the weakening of the cement's hydration products by the gypsum formation, which is accompanied by moderate expansion.

Slag is widely used as a mineral addition for cement in hydraulic structures. It is particularly suitable for use in structures such as dams as it improves some properties of cement by reducing heat of hydration and also mitigating alkali-aggregate reaction. The objective of this experimental program was to assess the influence of the sulfides on the mechanical properties of concretes prepared with reference cement (referred to in Brazil as CP II F-32) and cements with mass replacement of $40 \%$ and $60 \%$ of slag and aggregates of quartzmuscovite-schist with high sulfide content.

\section{MATERIALS E METHODS}

The materials used in the preparation of the concrete test specimens were:

- Ordinary Portland cements with carbonate filler (6\% to 10\%) - CP II-F-32 Brazilian type (CPII),

- $\quad$ CP II with partial replacement by $40 \%$ of slag, in mass (CP40);

- CP II with partial replacement by $60 \%$ of slag, in mass (CP60).

- Quartz-muscovite-schist litotype aggregate containing sulfides (pyrrhotite, pyrite and chalcopyrite), maximum size of $19 \mathrm{~mm}$;

- Artificial sand from quartz-muscovite-schist containing sulfides;

- Natural quartz sand.

The cements used in the experimental program were characterized by physical and chemical analyses and the main features are presented in Tables 1 and 2. Table 3 shows the chemical composition of blast furnace slag and Table 4 shows the physical characterization results of the coarse and fine aggregate used.

Table 1: Physical characteristics of cementitious materials (\%).

\begin{tabular}{|c|c|c|c|c|c|c|c|}
\hline & \multirow{2}{*}{$\begin{array}{c}\text { Density } \\
\text { Cementitious Material }\end{array}$} & \multicolumn{2}{|c|}{$\begin{array}{c}\text { Blaine } \\
\text { Fineness } \\
\left(\mathbf{c m}^{2} / \mathbf{g}\right)\end{array}$} & \multicolumn{2}{|c|}{$\begin{array}{c}\text { Setting time } \\
\text { (hour:min) }\end{array}$} & \multicolumn{4}{|c|}{$\begin{array}{c}\text { Compressive Strength } \\
\text { (MPa) }\end{array}$} \\
\cline { 4 - 8 } & & & Initial & Final & 3days & 7days & 28days \\
\hline CPII & 3.09 & 3540 & $02: 10$ & $03: 20$ & 23.6 & 27.9 & 34.4 \\
\hline CP40 & 2.99 & 3161 & $02: 50$ & $04: 20$ & 15.4 & 23.5 & 40.0 \\
\hline CP60 & 2.96 & 3100 & $03: 10$ & $04: 40$ & 9.6 & 19.4 & 36.4 \\
\hline
\end{tabular}


Table 2: Chemical characteristics of cementitious materials (\%).

\begin{tabular}{|c|c|c|c|c|c|c|c|c|c|c|c|c|}
\hline $\begin{array}{c}\text { Cementitious } \\
\text { Material }\end{array}$ & $\mathrm{SiO}_{2}$ & $\mathrm{Al}_{2} \mathrm{O}_{3}$ & $\mathrm{Fe}_{2} \mathrm{O}_{3}$ & $\mathrm{CaO}$ & $\mathbf{M g O}$ & $\mathrm{Na}_{2} \mathbf{O}$ & $\mathrm{K}_{2} \mathbf{O}$ & $\begin{array}{c}\mathrm{Na}_{2} \mathrm{O}_{\text {eq }} \\
\text { Totals }\end{array}$ & $\begin{array}{c}\text { Loss } \\
\text { on } \\
\text { ignition }\end{array}$ & $\mathbf{S O}_{3}$ & $\begin{array}{c}\text { Free } \\
\text { Lime }\end{array}$ & $\begin{array}{c}\text { Insoluble } \\
\text { residue }\end{array}$ \\
\hline $\mathrm{CPII}$ & 19.44 & 5.48 & 3.73 & 62.88 & 1.39 & 0.24 & 0.41 & 0.51 & 3.13 & 2.52 & 2.23 & 0.93 \\
\hline $\mathrm{CP} 40$ & 25.91 & 7.79 & 2.66 & 54.48 & 3.93 & 0.28 & 0.45 & 0.49 & 2.45 & 1.93 & 1.30 & 0.72 \\
\hline $\mathrm{CP} 60$ & 29.11 & 9.05 & 2.40 & 50.54 & 4.82 & 0.23 & 0.55 & 0.59 & 1.14 & 1.38 & 0.90 & 0.52 \\
\hline
\end{tabular}

Note: $\mathrm{Na}_{2} \mathrm{O}_{\text {eq }}=0.658 \mathrm{~K}_{2} \mathrm{O}+\mathrm{Na}_{2} \mathrm{O}$.

Table 3: Chemical characteristics of blast furnace slag (\%).

\begin{tabular}{|c|c|c|c|c|c|c|c|c|c|c|c|c|}
\hline $\begin{array}{c}\text { Chemical } \\
\text { composition }\end{array}$ & $\mathrm{SiO}_{2}$ & $\mathrm{Al}_{2} \mathrm{O}_{3}$ & $\mathrm{Fe}_{2} \mathrm{O}_{3}$ & $\mathbf{C a O}$ & $\mathbf{M g O}$ & $\mathrm{Na}_{2} \mathbf{O}$ & $\mathbf{K}_{2} \mathbf{O}$ & $\begin{array}{c}\mathrm{Na}_{2} \mathrm{O}_{\text {eq }} \\
\text { Totals }\end{array}$ & $\begin{array}{c}\text { Loss } \\
\text { on } \\
\text { ignition }\end{array}$ & $\mathbf{S O}_{3}$ & $\begin{array}{c}\text { Free } \\
\text { Lime }\end{array}$ & $\begin{array}{c}\text { Insoluble } \\
\text { residue }\end{array}$ \\
\hline Blast furnace slag & 35.04 & 12.43 & 0.16 & 41.58 & 8.68 & 0.31 & 0.55 & 0.67 & 0.31 & 0.12 & - & - \\
\hline
\end{tabular}

Table 4: Coarse and fine aggregate characteristics.

\begin{tabular}{|l|l|l|l|}
\hline Characteristics & \multicolumn{1}{|c|}{$\begin{array}{c}\text { Coarse Aggregate } \\
\text { Maximum Size of } \\
\mathbf{1 9} \mathbf{~ m m}\end{array}$} & $\begin{array}{c}\text { Artificial Fine } \\
\text { Aggregate }\end{array}$ & $\begin{array}{c}\text { Natural } \\
\text { Fine Aggregate }\end{array}$ \\
\hline Specific gravity $\left(\mathrm{kg} / \mathrm{m}^{3}\right)$ & 2.74 & 2.79 & 2.62 \\
\hline Absorption (\%) & 0.6 & 0.2 & 0.4 \\
\hline Fineness Modulus (M.F.) & 6.41 & 2.69 & 2.99 \\
\hline Content of powdered material (\%) & - & 17.48 & 0.99 \\
\hline Los Angeles (\%) & $25 \%$ & - & - \\
\hline
\end{tabular}

The concretes studied had the following mix design: $467 \mathrm{~kg} / \mathrm{m}^{3}$ of cement, $1018 \mathrm{~kg} / \mathrm{m}^{3}$ of coarse aggregate containing sulfides [maximum size of $19 \mathrm{~mm}$ ], $183 \mathrm{~kg} / \mathrm{m}^{3}$ of artificial sand containing sulfides, 495 $\mathrm{kg} / \mathrm{m}^{3}$ of natural sand, water/cement ratio equal to 0.45 and slump of about $90 \mathrm{~mm}$. The prismatic and cylindrical test specimens cast for the experimental program were stored in a moist room with the temperature kept at $23^{\circ} \mathrm{C} \pm 2{ }^{\circ} \mathrm{C}$ and the relative humidity higher than $90 \%$.

Moreover, before using the aggregates in the concrete preparation, the polished sections of the crushed aggregate (powder) from profile cuts were analyzed by reflected light optical microscopy using an Axioskop 40 Pol Zeiss optical microscope and a Leica DFC280 digital camera model with QwinThus image software. A qualitative analysis was initially performed to identify the mineralogical composition, and a quantitative analysis to determine the percentage of sulfide minerals in the section representing the analyzed aggregate, obtained through a modal analysis.

All concrete prismatic specimens were visually inspected in order to determine the presence of typical symptoms of unstable sulfides contained in the aggregates used in the composition of the system, over time.

The cylindrical test specimens $(100 \mathrm{~mm}$ x $200 \mathrm{~mm})$ were cast in order to determine the compressive strength and modulus of elasticity of the concretes and of the prismatic ones (75 $\mathrm{mm} \times 75 \mathrm{~mm}$ x $285 \mathrm{~mm})$ to assess the expansion phenomenon of the concretes investigated over time in the presence of aggregates containing sulfides. This phenomenon was determined by the specimens' length variation using a specific apparatus, according to ASTM C-490/2011 [10]. 
The cylindrical specimens were used to determine the compressive strength and modulus of elasticity of the concretes at 28,90,182,510, and 1095 days of age, respectively, in accordance with the Brazilian standard ABNT NBR 5739:2007 [11], similar to ASTM C-39/2012 [12] and the standard ABNT NBR 8522:2008 [13]. After the completion of this test, samples of aggregates and mortars were extracted from the concretes at specific ages. The aggregates were subjected to microstructural analysis using optical microscope in order to investigate and assess the mineralogical changes, specifically the sulfides contained in the aggregates extracted from the investigated concretes, after their oxidation.

X-ray diffraction and scanning electron microscopy analyses (Siemens D5000 X-Ray diffractometer and SEM Leica S440i) were performed on the concrete mortars to identify deleterious neoformed products resulting from the alteration process of the sulfides in the aggregates used in the concretes.

\section{RESULTS}

The results concerning the main physicochemical alterations of the aggregate's microstructure containing sulfides and the expansion, compressive strength and modulus of elasticity of the concretes over time were presented.

\subsection{Optical Microscopy}

The sulfide-containing aggregate was characterized as quartz-muscovite-schist by transmitted light optical microscopy before being used in the concretes. It is primarily composed of $60-65 \%$ of quartz, $30 \%$ of muscovite, $<10 \%$ of opaque minerals and carbon matter, and $<5 \%$ of garnet, biotite, and chlorite. Sulfides are opaque minerals which can only be identified by reflected light. Thereby, by means of reflected light optical microscopy, it was possible to identify the opaque and quantify the sulfides in the aggregates under study. The quantification of the sulfides in the polished sections of the aggregate powder provided an average of $3.9 \%$ total sulfides and of that total, $3.3 \%$ correspond to pyrrhotite $\left(\mathrm{Fe}_{1-\mathrm{x}} \mathrm{S}\right), 0.3 \%$ to pyrite $\left(\mathrm{FeS}_{2}\right), 0.2 \%$ to marcasite $\left(\mathrm{FeS}_{2}\right)$, and $0.1 \%$ to chalcopyrite $(\mathrm{CuFeS})$. Figure 1 shows the sulfide minerals, oxides, and transparent minerals such as silicates that were identified.

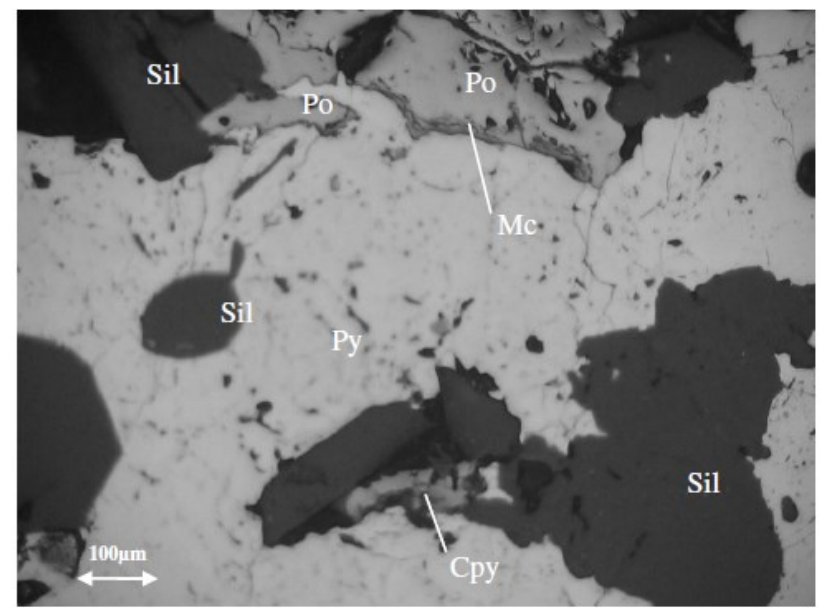

Figure 1: Photomicrograph of a large pyrrhotite (Po) crystal with incipient alteration to marcasite (Mc) in contact with pyrite (Py), inclusion of chalcopyrite (Cpy) and intergrowth with silicate (Sil).

However, when analyzing, over time, the aggregates extracted from the CPII concrete, it was observed that the iron sulfides and mainly pyrrhotite were under intense oxidation. Another important finding and perhaps the most important one reported on the results obtained by using the reflected light optical microscopy has to do with the alteration rate of the pyrrhotite. It was observed that this mineral was already under the alteration process after only 28 days inside the concrete. It was also shown that the aggregates with iron sulfides selected from the concretes at that stage of the investigation presented alteration, initially for marcasite (Mc) and in the sequence for limonite (Lm), as recorded at 28 days of age in Figure 2, for 90 days in Figure 3 and, lastly, at 1095 days in Figure 4. The same behavior was observed in the aggregates extracted from the concretes with $\mathrm{CP} 40$ and CP60, as shown in Figure 5 for CP40 at 90 days and in Figure 6 for CP60 at 1095 days. 


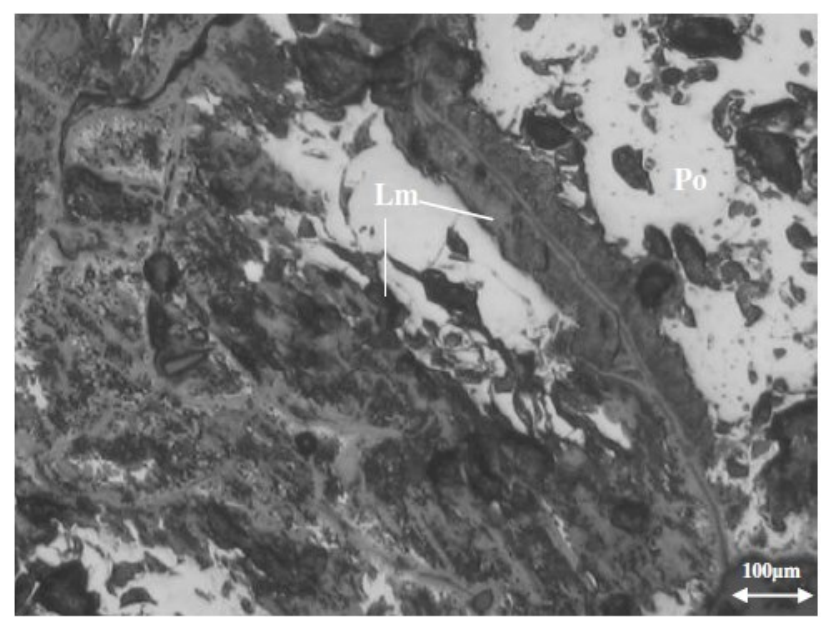

Figure 2: Photomicrography of the aggregate containing sulfides extracted from the CPII at 28 days: Pyrrhotite (Po) with intense oxidation to limonite $(\mathrm{Lm})$ from the fractures.

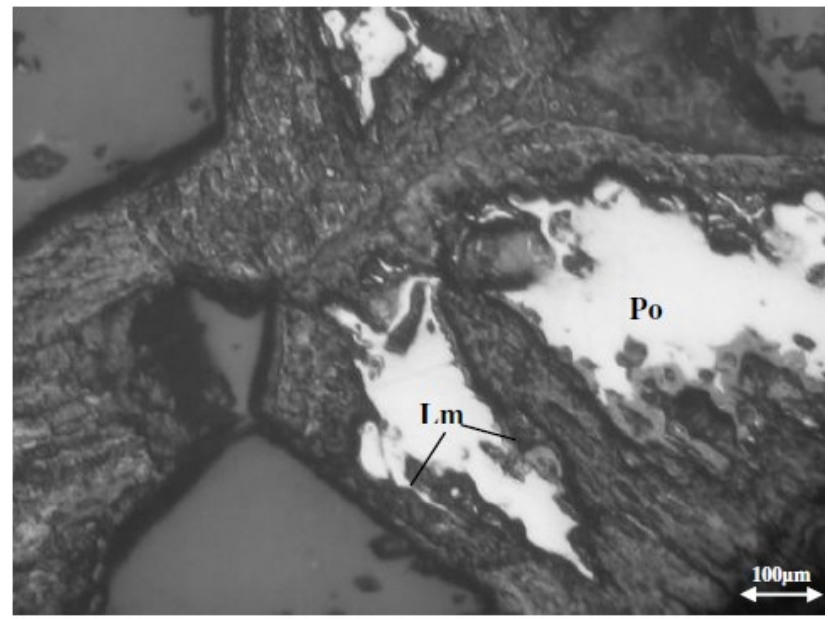

Figure 3: Photomicrography of the aggregate containing sulfides extracted from the CPII at 90 days: Pyrrhotite (Po) with intense oxidation to limonite $(\mathrm{Lm})$ from the fractures.

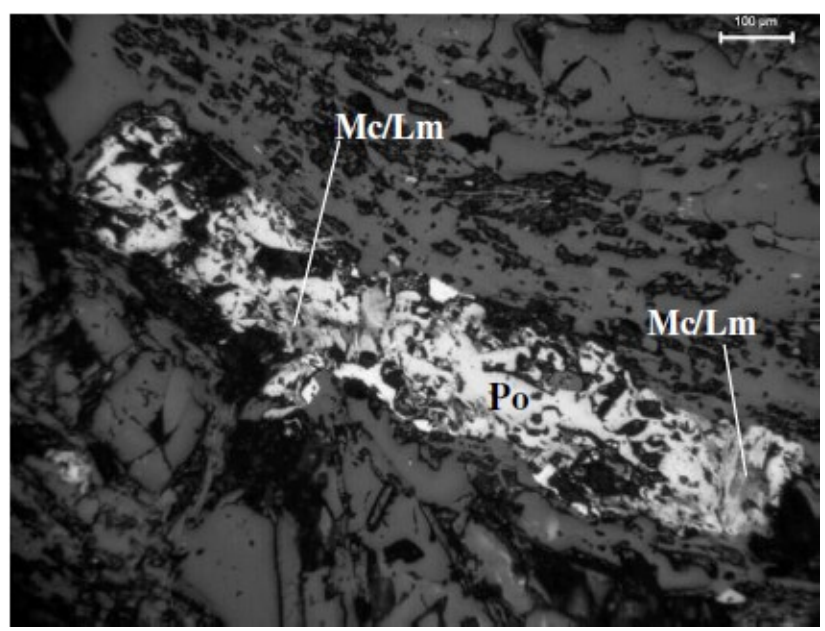

Figure 4: Photomicrography of the aggregate containing sulfides from the CPII at 1095 days: large fragment of pyrrhotite $(\mathrm{Po})$ changing to marcasite and $(\mathrm{Mc})$ and limonite $(\mathrm{Lm})$. 


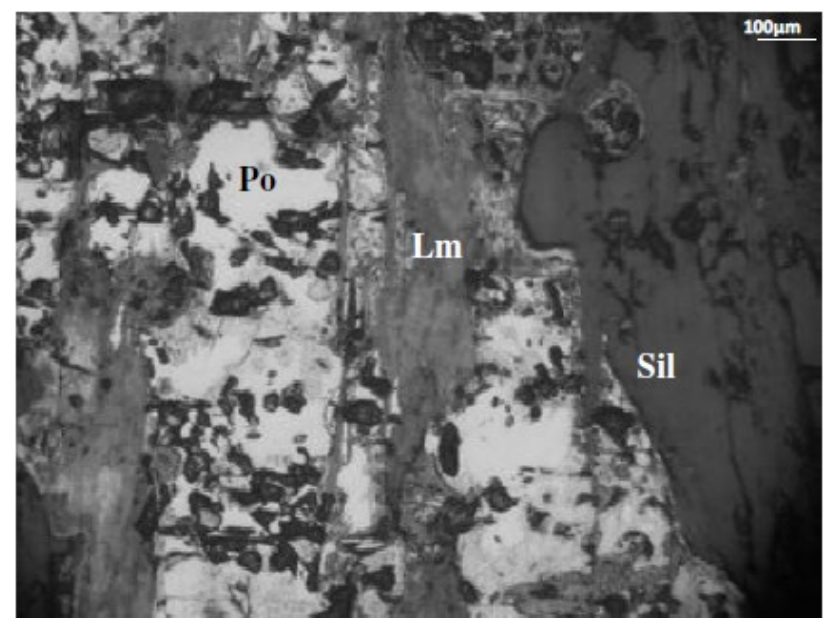

Figure 5: Photomicrography of the aggregate containing sulfides from the CP 40 at 90 days: Pyrrhotite (Po) changing to marcasite and $(\mathrm{Mc})$ and limonite $(\mathrm{Lm})$.

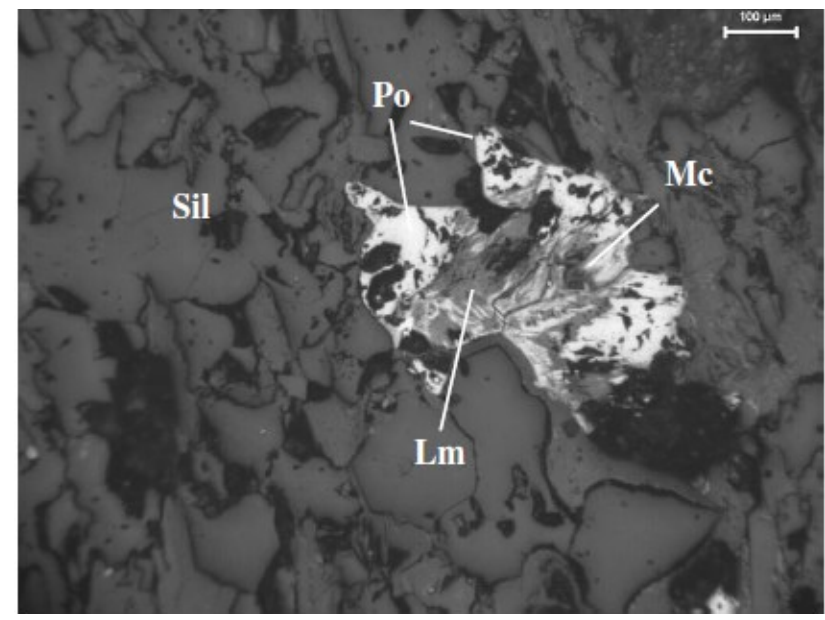

Figure 6: Photomicrograph of aggregate containing sulfides extracted from CP60 at 1095 days: Large fragment of pyrrhotite $(\mathrm{Po})$ changing to marcasite $(\mathrm{Mc})$ and limonite $(\mathrm{Lm})$ from the internal fractures.

Ultimately, the analysis enables confirming that the pyrrhotite is the most reactive mineral in the system, hence the one primarily responsible for the changes observed in the aggregates [5,7]. Furthermore, it shows that the presence of moisture is essential to accelerate the alteration process of the iron sulfides [14].

To corroborate the aforementioned statements, the visual and tactile tests carried out on the concretes revealed that the inside of the concretes was wet. In addition, an unpleasant rancid odor similar to the smell of sulfur was detected after the rupture of the concrete. This is due to the release of hydrogen sulfide $\left(\mathrm{H}_{2} \mathrm{~S}\right)$, typical of the oxidation of sulfide minerals.

Concerning the humidity detected inside the concretes investigated, some assumptions can be made to justify their evident presence. It is known that the aggregates used are schistous, characterized by the presence of oriented micaceous minerals, whose laminar structure can promote the increased permeability and porosity of the system [3]. Consequently, the alteration process of the sulfides may be accelerated. This may have first occurred with the sulfide-containing aggregates being close to the surface of the concretes. With the alteration of these sulfides, products with higher volumes in the mineral may have formed, which promoted the cracking of the aggregate resulting in the microcracking of the concrete mortar [3, 4, 15,16], as observed by GOMIDES [4] in Figure 7. Thus, the process would be intensified over time, as seen by the appearance of microcracks in both aggregates as well as in the concrete mortar. These new microcracks could make it easier for the entry of additional moisture and oxygen into the system, possibly resulting in the deterioration of the aggregate itself and consequently of the concrete. 


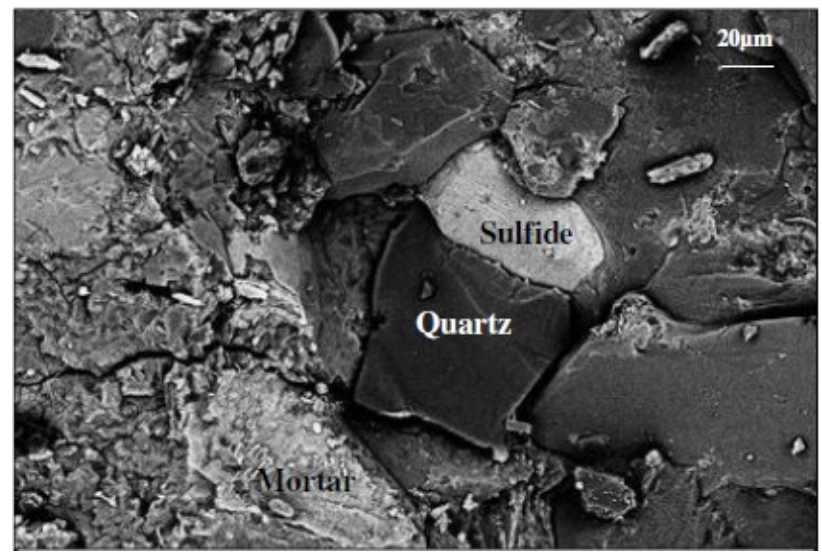

Figure 7: Photomicrograph of the concrete mortar extracted from the CP60: interface mortar/aggregate containing sulfides. Presence of cracks and fragmentation of both systems.

\subsection{Microstructural Analyses: X-Ray Diffraction and Scanning Electron Microscopy}

The X-ray diffraction and scanning electron microscopy analyses performed on the mortars extracted from the investigated concretes were also important as it helped identify the products formed over time due to the alteration process of the sulfides found in the aggregates.

The main crystalline products identified were portlandite (calcium hydroxide), ettringite, and gypsum. These products were found in all concretes prepared with CPII, CP40 and CP60, virtually at all ages studied $(28,90,182$ and 1095 days). It is well known that ettringite and gypsum can be found in hydrated cement paste. However, these products may also be indicative of intrinsic changes in concrete due to deleterious reactions between the phases of cement paste and the aggressive ions $\left(\mathrm{SO}_{4}{ }^{2-}\right.$ and $\left.\mathrm{H}^{+}\right)$released, as it is known, during the alteration process of the sulfides $[4,5,6,8,17]$.

Numerous studies have shown that ettringite and gypsum are typical products of traditional sulfate attacks, which are responsible for causing the appearance of several pathological events that can lead to the complete deterioration of concrete structures. The formation of ettringite crystals can trigger the expansion of concrete and consequently the cracking of this material $[14,18]$. With regards to gypsum, it can promote the progressive reduction of compressive strength, stiffness, and loss of concrete mass due to the weakening or breakdown of the hydration products on cement paste $[18,19]$.

\subsection{Expansion}

The expansion results over time on the cast concretes are shown in Figure 8 through curves adjusted by the mathematical modeling of the results. The concretes showed similar behavior, with exponential-type modeling. Figure 8 shows that over time the expansion increases gradually and more pronounced, regardless of the type of binder used for preparing the concrete. This behavior can be directly related to the formation of expansive products such as ettringite and gypsum, which may be the result of the chemical reactions between the hydrated phases of the cement paste and the sulfate ions released by the sulfide alterations found in high concentrations in the aggregates used for preparing this concrete. 


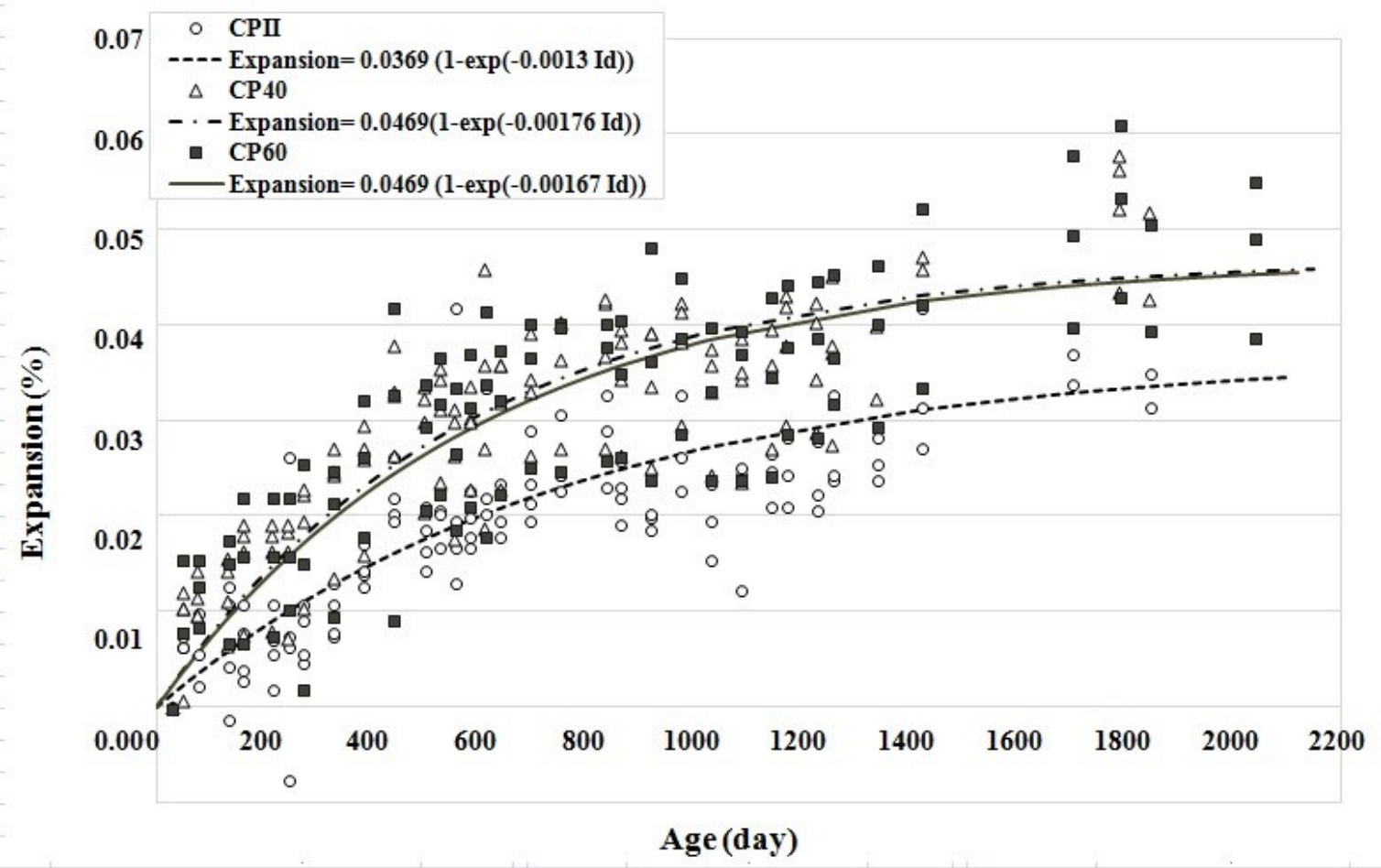

Figure 8: Expansion: curves fitting the experimental results determined for each cast concrete.

\subsection{Compressive Strength}

Figure 9 graphically shows the adjusted curves and their experimental results for each concrete. According to Figure 9, it can be observed that the compressive strength of the concretes grows gradually and noticeably, over time. No other behavior could be expected, since the analyses performed by optical microscopy revealed an intense oxidation of the sulfides, which resulted in the availability of sulfate ions for the system and the consequent formation of expansive products such as ettringite and gypsum identified by X-ray diffraction and by scanning electron microscopy. In addition to these, other products resulting from the oxidation of sulfides were also found by optical microscopy, namely ferrihydrites. When these products are formed within the pores or when deposited into the voids of the mortar, as well as in the paste/aggregate interface, they can fill those spaces hence promoting a densification of the matrix and gaining strength [4]. However, once their accommodation capacity reaches its limit state, cracking will develop in the concrete, which will then promote the entry of aggressive agents into the interior of the material, or in the case of this study, act as accelerating agents in the oxidation process of the minerals: moisture and oxygen [4, 14]. Thus, as there are still unaltered or unchanged sulfides in the aggregates, according to the optical microscopy analysis, their oxidation can still occur and new products can form. In the course of this process the internal tensions can be intensified and the final effect would be to gradually reduce the concrete's resistance capacity [20, 21]. 


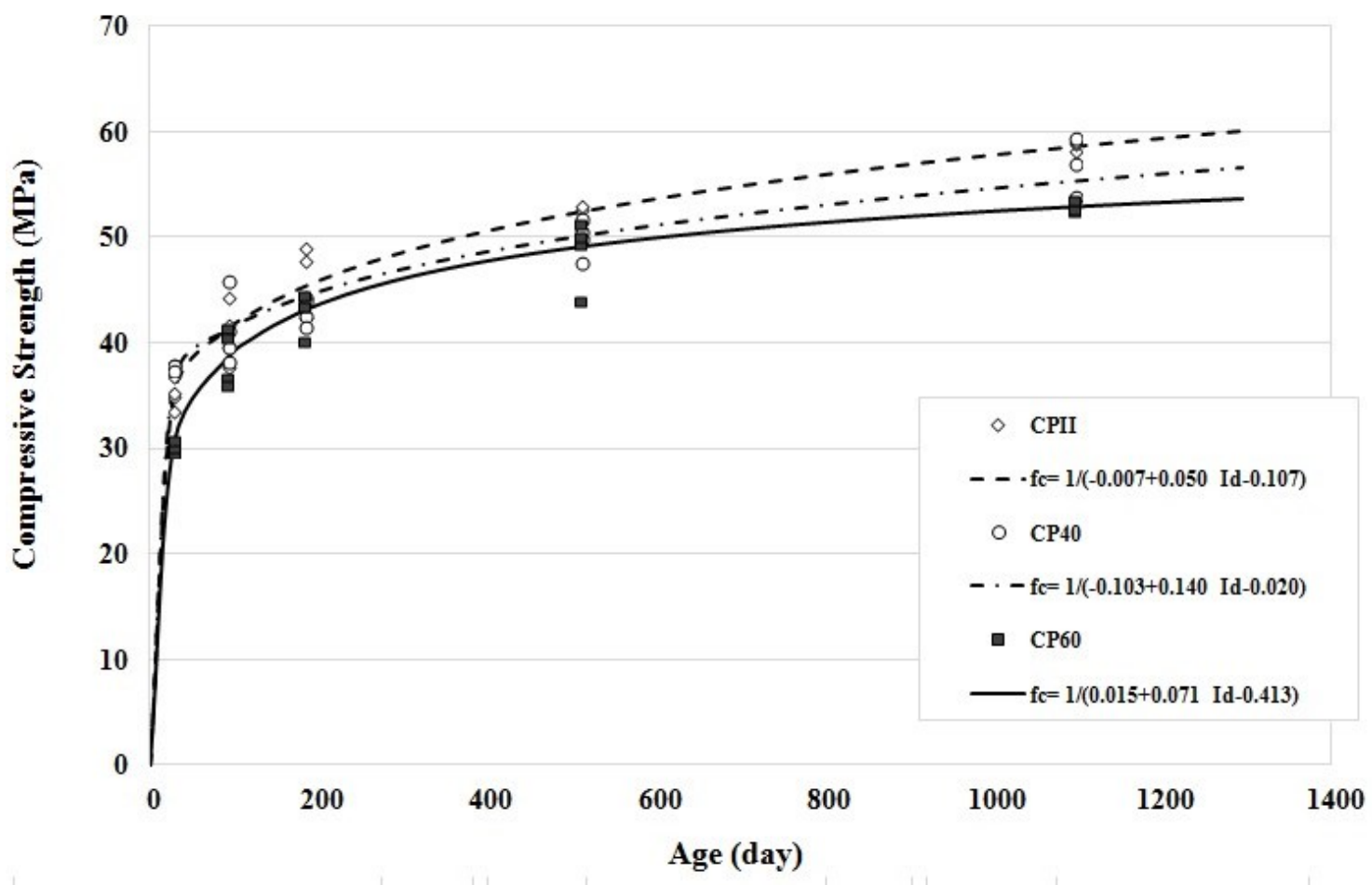

Figure 9: Compressive strength: curves adjusted to the experimental results for each cast concrete.

In order to check whether there is homogeneity of concrete in relation to the type of binder, the Duncan test with multiple comparisons of means was performed. It was found that the experimental results for each concrete resulted in very close averages, but even so, two distinct groups were obtained. The first group (concrete CP40 and CPII), showed higher mean compressive strength values, around 9\%, in comparison with the mean values obtained for the second group (concrete CP60). However, these results require caution. The increased CPII compression strength until 1095 days of age was probably due to the increased concentration of formed products, ettringite, in the pores as evidenced by XRD (X ray diffraction) and SEM (scanning electron microscopy). Therefore, the internal attack by sulfates may have only served to increase the mechanical strength of the concrete, i.e., not initiated the critical phase of the attack, considering that the CPII mortars were still dense and with few cracks compared to CP40.

\subsection{Modulus of Elasticity}

Several attempts had been made to adjust the results obtained for determining the modulus of elasticity achieved in the concretes. However, the experimental results of concretes CP60 and CPII did not allow a proper fit. The model showed that the only concrete results that could be adjusted regarded CP40. Figure 10 graphically shows the experimental results for each particular curve and adjustment of CP40. It is noted that only after 90 days of age, the behavior of CPII, CP40 and CP60 differ among themselves, however, not significantly. Furthermore, over time there was tendency towards stabilization for this property in the three concretes investigated. 


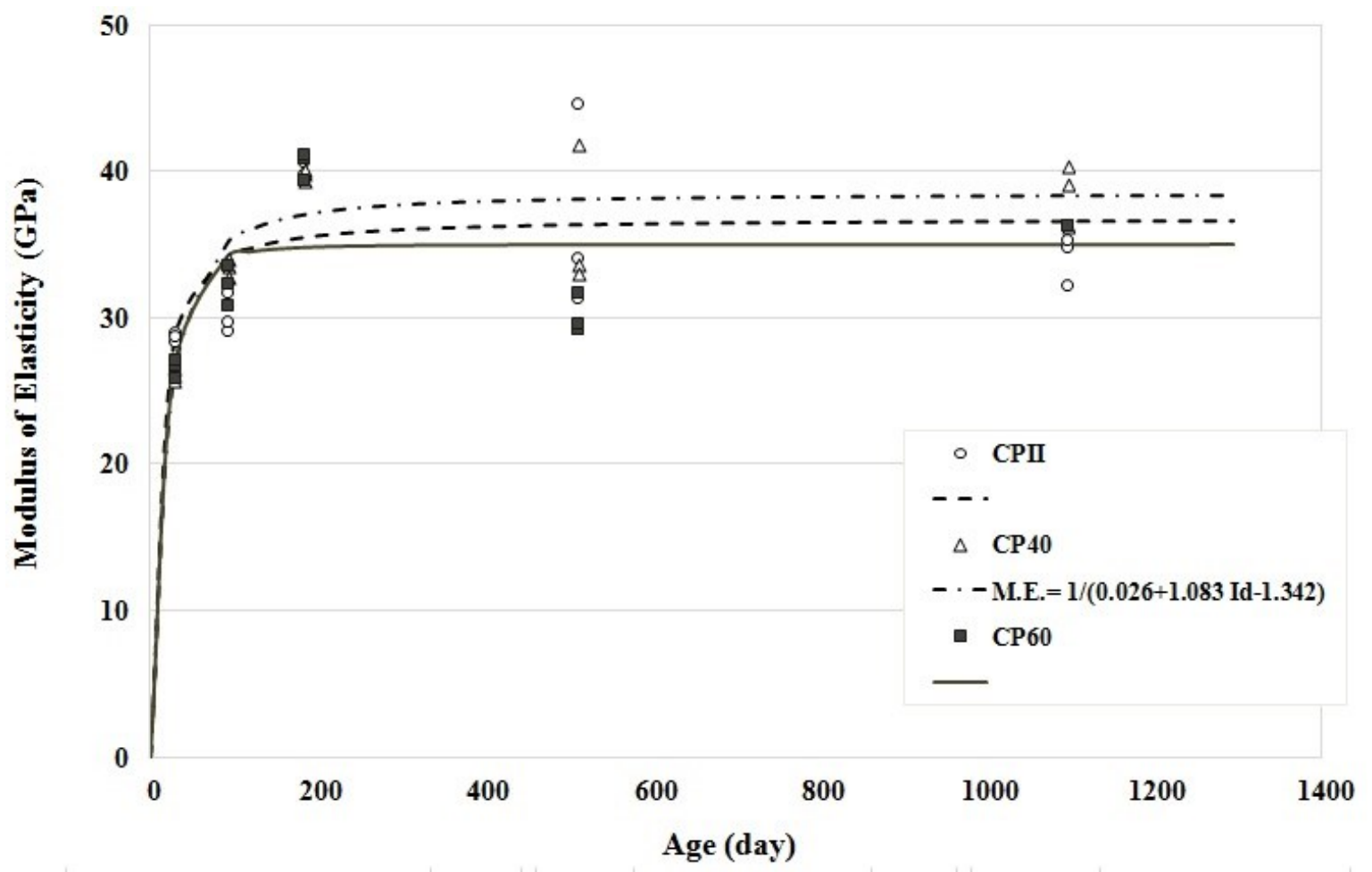

Figure 10: Modulus of elasticity: experimental results and curves adjustments to the experimental results for each individual prepared.

In order to check whether there is homogeneity of the concretes investigated in relation to the type of binder, the Duncan multiple comparison of means test was performed. According to Duncan's method, there were no significant differences between the binders used in terms of modulus of elasticity.

\section{DISCUSSION}

The influence of the main physicochemical alterations of the aggregate's microstructure containing sulfides on the performance of each concrete studied was assessed.

\subsection{Expansion}

According to CASANOVA et al. [15], the formation of ettringite crystals can promote a volumetric variation in the sulfide mineral within the system equal to $172.19 \mathrm{~cm}^{3} / \mathrm{mol}$ of sulfate. In the case of gypsum, the variation is much lower than that of ettringite, on the order of $41.63 \mathrm{~cm}^{3} / \mathrm{mol}$ of sulfate. To confirm that the expansion observed in the concretes is related to the formation of ettringite and gypsum, the XRD and SEM analyses carried out substantiated the presence of both products.

A kinetic model to quantify the expansion due to the iron sulfide oxidation, as well as the secondary ettringite formation in the concrete, was proposed in 2013 [22]. The model allows a direct prediction of the expansion generated by the internal sulfate attack, taking into account the physical and chemical characteristics of the concrete and of the aggregate.

The expansion mechanism caused by the formation of deleterious products in the internal sulfate attacks can be summarized as follows: In the early stages, the expansive products ettringite and/or gypsum are formed in the voids and pores of the paste, but do not cause internal tensions. Over time, these products begin to fill the voids and pores of the paste, thus reducing their ability to be accommodated in the internal porous structure of the concrete paste. As a result, internal stresses produced in the material can begin, which are supported by the preserved regions of the cement paste. From the moment the preserved region can no longer withstand the tensile strength generated by the products formed, the expansion phenomenon begins to develop in the concrete [4].

The mortar of the concretes with slag cement (CP40 and CP60) were less dense, more fragile, with some dustiness, and with the presence of microcracks in the matrix, a characteristic that may contribute to accelerating the expansion of the system [23]. These characteristics, with the exception of microcracks, were 
not observed in concrete CPII. Therefore, it is concluded that the internal microstructure of concrete prepared with slag cement (CP40 and CP60) contributed to the expansion developing faster and more intensely in these concretes, reaching the value of $0.04 \%$ after 1029 days of age.

It is also reported that after approximately 1,900 days (more than 5 years under study) the expansions tend to stabilize, which is likely due to the consumption of the aluminate phases of the cement paste, including the reduction of the amount of sulfate ions released by the oxidation of the sulfides, given that these change over time. Therefore, these factors may have contributed to the reduction of the dynamics of the existing process [4]. It is believed that the main deleterious effect resulting from the expansion, i.e., the formation of microcracks in the system, can contribute to this stability as new "spaces" are generated within the paste, which can cause the reduction in the intensity of the expansion in a given period of time. However, over time these "spaces" can also be filled by new products that will be formed when there are sulfate ions in the system; thus, the expansion process will continue. Furthermore, these microcracks can cause the appearance of other pathological phenomena which, together with the internal attack by sulfates, can accelerate the deterioration of the concrete [14].

\subsection{Compressive Strength}

In the situation studied, the internal sulfate attack in CP40 at 28 days of age promoted a "seemingly" beneficial effect, i.e., a resistance gain. This probably resulted from the formation of ettringite and gypsum, products identified by XRD and SEM. To confirm the previous statement, the performance of CP60, which contains a higher content of slag (60\%), was analyzed. It appears that the concrete always had the lowest resistance values, probably a consequence of the lower concentration of calcium hydroxide in the system, leading to the sulfate ion attack in the C-S-H phases, which are responsible for paste strength. This is most apparent with the visual inspections performed on the external surfaces of the concrete prepared with slag, which is found in the worst pathological manifestations resulting from this deleterious phenomenon; namely, the disintegration or deterioration of the material, which is intensified in the CP60.

The aforementioned results corroborate the fact that the compressive strength test may not be the most appropriate for evaluating the deterioration and internal attack by sulfates $[4,24]$ due to the alteration of the sulfides, since this property might even be favored, depending on the microstructure and stage of the attack.

\subsection{Modulus of Elasticity}

The aforementioned analyses allow us to state that, regardless of the binder used, the modulus of elasticity was compromised by the high concentration of sulfides in the aggregate. Two phenomena may have possibly contributed to this behavior: First, the internal attack by sulfates, which resulted in the formation of products at the paste/aggregate interface. Second, the physical and mineralogical changes in the aggregate caused by the oxidation of sulfides over time, as detected by images via optical microscopy. However, jointly these two phenomena have not yet been able to significantly affect the modulus of elasticity, i.e., not sufficiently, during the evaluation period, to promote the reduction or decrease in this property, as would be expected for expansive reactions [25]. This justifies the assertion in the curves relating to the setting of each individual modulus, i.e., the stabilization of this property after 182 days. Moreover, the intrinsic alterations have to be taken into consideration due of the oxidation process of sulfides, which is not yet known.

\section{CONCLUSIONS}

Pathological manifestations (specifically, white efflorescence spots, spalling, and disintegration) resulted from the sulfide oxidation process, which became more intense with increasing content of slag cement used to partially replace the reference binder (CP II), i.e., CP40 and CP60 in concrete. In this context, these concretes, since approximately 4 years of age, were already brittle and powdery, reaching a breakdown state after 5 years.

The three concretes investigated were prepared with aggregates containing $3.89 \%$ sulfides. Two of the concretes prepared with different amounts of slag (CP40 and CP60), in which the concentration of aluminate ions was greater than $7.5 \%$, showed greater expansions than the reference concrete (CPII), carried out using binder containing lower concentrations of these ions, and whose paste had become more porous. Thus, the slag cement, chosen to partially replace the reference binder (CP II), regardless of its concentration, had no beneficial effect. More specifically, it did not contribute to minimizing the phenomenon expansion due to the formation of deleterious products such as ettringite and gypsum, derived from the oxidation of sulfides present in aggregates (internal sulfate attack). 
The compressive strength test was not found to be the most appropriate for evaluating an internal sulfate attack due to sulfide oxidation, as the "apparently" beneficial effect obtained, namely the growth of this property, over time, can generate a false interpretation of concrete performance.

Typical elastic modulus results for the concrete investigated revealed that the oxidation of sulfides interfered intrinsically, but also varied for this property over time, probably due to the heterogeneity of the oxidation phenomenon.

\section{ACKNOWLEDGMENTS}

The authors wish to express their gratitude to the research and development program of ANEEL (Nacional Electric Energy Agency), engineer Nicole Pagan Hasparyk and Eletrobrás Furnas, in Goiânia, Brazil, for the financial and technical support for this research.

\section{BIBLIOGRAPHY}

[1] CHICHÓN, J.S., AYORA, C., AGUADO, A., et al., "Influence of Weathering of Iron Sulfides Contained in Aggregates on Concrete Durability", Cement and Concrete Research, v. 25, n. 6, pp. 1264-1272, 1995.

[2] AGUADO, A., AGULlÓ, L., CAROL, I., et al., "Análisis del comportamiento estructural del hormigón: de la micro a la macro estructura - Aplicación al caso de presas”, Hormigón y Acero, n. 233, pp. 145-158, 2004.

[3] TAGNIT-HAMOU, A., SARIC-CORIC, M., RIVARD P. "Internal deterioration of concrete by oxidation of pyrrhotitic aggregates”, Cement and concrete research, v. 35, n. 1, pp. 99-107, 2005.

[4] GOMIDES, M. J. Investigação de agregados contendo sulfetos e seus efeitos sobre a durabilidade do concreto, [Research about Aggregates containing sulfides and their effects on the durability of concrete], Tese de D.Sc, Postgraduate Program in Engineering/Federal University of Rio Grande do Sul (UFRGS), Porto Alegre, Brazil, 2009.

[5] SCHMIDT, T., LEEMANN, A., GALLUCCI, E., et al., "Physical and microstructural aspects of iron sulfide degradation in concrete", Cement and Concrete Research, v. 41, n.3, pp. 263-269, 2011.

[6] RODRIGUES, A., DUCHESNE, J., FOURNIER, B., et al., "Mineralogical and chemical assessment of concrete damaged by the oxidation of sulfide-bearing aggregates: Importance of thaumasite formation on reaction mechanisms", Cement and Concrete Research, v. 42, n. 10, pp. 1336-1347, 2012.

[7] CASANOVA, I., LÓPEZ, C.M., AGUADO, A., et al., "Micro and Mesoscale Modeling of Expansion in Concrete Dams", In: Proceedings of International Symposium on New Trends and Guidelines on Dam Safety, v. 1, pp. 661-667, ed. L. Berga, Barcelona, 1998.

[8] AYORA, C., CHICÓN, S., AGUADO, A., et al., "Weathering of Iron Sulfides and Concrete Alteration: Thermodynamic Model and Observation in Dams from Central Pyreness, Spain", Cement and Concrete Research, v. 28, n. 9, 1223-1235, 1998.

[9] IRASSAR, E. F., BONAVETTI, V. L., MENÉNDEZ, G. "Cementos con Material Calcáreo: Formación de Thaumasita por Ataque de Sulfato”, Revista de la Construcción, v. 9, n. 1, pp. 63 - 73, 2010.

[10] AMERICAN SOCIETY FOR TESTING AND MATERIALS (ASTM): Standard practice for use of apparatus for the determination of length change of hardened cement paste, mortar, and concrete, ASTM C490, West Conshohocken, 2011.

[11] ASSOCIAÇÃO BRASILEIRA DE NORMAS TÉCNICA (ABNT): Concreto - Ensaios de compressão de corpos-de-prova cilindricos, [Concrete - Compression test of cylindric specimens - Method], NBR 5739, Rio de Janeiro, 2007.

[12] AMERICAN SOCIETY FOR TESTING AND MATERIALS (ASTM): Standard test method for compressive strength of cylindrical concrete specimens, ASTM C 39/C 39M, West Conshohocken, 2012.

[13] ASSOCIAÇÃO BRASILEIRA DE NORMAS TÉCNICA (ABNT): Concreto - Determinação do módulo estático de elasticidade à compressão, NBR 8522, Rio de Janeiro, 2008.

[14] GOMIDES, M. J., CINCOTTO, M. A., HASPARYK, N. P., et al., "Study of aggregates with sulfides in cement composites", IBRACON Materials Journal, vol. 3, pp. 29-38, 2007.

[15] CASAnOVA, I., AGILlÓ, L., AGUADO, A., "Aggregate expansivity due to sulfide oxidation - II. Physico-chemical modeling of sulfate attack", Cement and concrete research, v. 27, n. 11, pp. 1627-1632, 1997. 
[16] PEREIRA, E., PORTELlA, K. F., BRAGANÇA, M. D. G. P., et al., "Oxidação da pirita e seus efeitos em argamassas de cimento Portland sujeitas ao ataque por sulfatos de origem interna [Pyrite Oxidation and its effects on Portland cement mortars subject to internal sulfates attack (ISA)]", Revista Matéria, v. 21, n. 2, pp. 342-354, 2016.

[17] MA, Y., LIN, C., "Microbial Oxidation of $\mathrm{Fe}^{2+}$ and Pyrite Exposed to Flux of Micromolar $\mathrm{H}_{2} \mathrm{O}_{2}$ in Acidic Media", Scientific Reports, 3, 1979, 2013.

[18] MEHTA, P. K., MONTEIRO, P. J. M., Concreto: estrutura, propriedades e materiais, 2 a ed., São Paulo, IBRACON, 2014.

[19] SANTHANAM, M., COHEN, M. D., OLEK, J., "Mechanism of sulfate attack: a fresh look part 2. Proposed mechanisms", Cement and concrete research, v. 33, n.3, pp. 341-346, 2003.

[20] AL-AMOUNDI, O.S.B., MASLEHUDDIN, M., SAADI, M.M., "Effect of magnesium sulfate and sodium sulfate on the durability performance of plain and blended cements", ACI Materials Journal, v. 92, n. 1, pp. 15-24, 1995.

[21] GOMIDES, M. J., Ataque por sulfatos a concreto compactado com rolo, [Attack of sulfates to roller compacted concrete], Tese de M.Sc, Postgraduate Course in Civil Engineering/Federal University of Goiás (UFG), Goiânia, Brazil, 2001.

[22] OLIVEIRA, I., CAVALARO, H. P. S., AGUADO, A., "New kinetic model to quantify the internal sulfate attack in concrete", Cement and Concrete Research, v. 43, pp. 95-104, 2013.

[23] PETROV, N., TAGNIT-HAMOU, A., "Is microcracking really a precursor to delayed ettringite formation and consequent expansion?, ACI Materials Journal, v. 101, n. 6, pp. 442-447, 2004.

[24] IRASSAR, E. F., "Sulfate resistance of blended cement: prediction and relation with flexural strength", Cement and concrete research, v. 20, n. 2, pp. 209-218, 1990.

[25] BRUNEATAUD, X., DIVET, L., DAMIDOT, D., "Impact of unrestrained delayed ettringite formationinduced expansion on concrete mechanical properties", Cement and concrete research, v. 38, n.11, pp. 13431348,2008 